\title{
Effects of oocyte maturation regimen on the relative abundance of gene transcripts in bovine blastocysts derived in vitro or in vivo
}

\author{
H. M. Knijn ${ }^{1}$, C. Wrenzycki ${ }^{2}$, P. J. M. Hendriksen ${ }^{1}$, \\ P. L. A. M. Vos ${ }^{1}$, D. Herrmann ${ }^{2}$, G. C. van der Weijden ${ }^{1}$, \\ H. Niemann ${ }^{2}$ and S. J. Dieleman ${ }^{1}$ \\ ${ }^{1}$ Department of Farm Animal Health, Faculty of Veterinary Medicine, University of Utrecht, \\ Yalelaan 7, 3584 CL Utrecht, The Netherlands; and ${ }^{2}$ Department of Biotechnology, Institut \\ für Tierzucht und Tierverhalten (FAL), Neustadt, Germany
}

\begin{abstract}
Bovine embryos produced in vitro differ substantially from embryos produced in vivo in the mRNA expression patterns of genes important for development. Several factors in the in vitro production systems have profound effects on embryonic mRNA expression patterns. The effects of the type of maturation on the expression pattern of genes important for development in blastocysts produced in vitro have not yet been investigated. The aim of the present study was to investigate the effects of various maturational protocols on the relative abundance of a panel of six marker genes, indicative of compaction and cavitation, metabolism, stress susceptibility and RNA processing, in bovine blastocysts produced in vitro. Four groups of blastocysts were analysed by a sensitive semiquantitative RT-PCR assay. Blastocysts were produced in vitro from oocytes of different origin from: (1) $3-8 \mathrm{~mm}$ follicles; (2) preovulatory follicles before the LH surge; and
\end{abstract}

\section{Introduction}

In cyclic cows, embryos develop after fertilization of oocytes that originate from an ovulatory follicle. These follicles have undergone the processes of selection, growth and dominance until oestrus, when the LH surge initiates the final maturation approximately $24 \mathrm{~h}$ before ovulation (Dieleman et al., 1983a; Fortune, 1994). In contrast, for production of viable embryos in vitro, oocytes are used that differ from oocytes originating from ovulatory follicles in vivo in that they are: (1) derived from immature, subordinate follicles of $2-8 \mathrm{~mm}$ in diameter, and (2) matured in vitro, outside the follicle. Oocytes from small follicles $(<2-3 \mathrm{~mm})$ are less likely to develop in vitro into blastocysts than are oocytes from larger $(>3 \mathrm{~mm}$ ) follicles (Pavlok et al., 1992; Blondin et al., 1997; Van de Leemput et al., 1999). A comparative analysis of the ultrastructure of oocytes derived from dominant, preovulatory follicles with

E-mail: H.Knijn@vet.uu.nl
(3) preovulatory follicles $\mathbf{2 4} \mathrm{h}$ after the $\mathrm{LH}$ surge. The first two groups were matured in vitro, whereas the third group had undergone maturation in vivo. A fourth group comprised blastocysts developed entirely in vivo. Expression of glucose transporter 1 was significantly $(P<0.05)$ higher, and expression of desmocollin 2 and plakophilin tended to be higher $(P<0.1)$ for in vivo (group 4) compared with in vitro blastocysts (group 1), whereas no differences were found for heat shock protein 70.1, E-cadherin and poly(A) polymerase. Expression of the six transcripts did not differ among blastocysts produced in vitro from oocytes of groups 1,2 and 3. Results indicate that alterations in the relative abundance of these transcripts in blastocysts produced in vitro cannot primarily be attributed to the origin of the oocyte, but are likely to have been induced by post-maturation or fertilization culture conditions. that of oocytes from subordinate, small follicles revealed first signs of maturation (referred to as 'capacitation' or 'prematuration') in the dominant follicle before the LH surge (Assey et al., 1994; Hyttel et al., 1997). Bovine oocytes contain large but changing populations of mRNAs and proteins. The oocyte supplies mRNAs that sustain embryonic development up to the stage of maternal-embryonic transition, and a few mRNAs persist throughout development until the blastocyst stage (Memili and First, 1999). In particular, the oocyte contains transcription factors involved in the minor and major activation of the embryonic genome at the two- to four-cell stage and eight-cell stage, respectively (Viuff et al., 1996). So, within the mammalian oocyte, genes have to be properly imprinted; furthermore, oocyte-derived factors are important for changes in methylation and for recognition of imprinted genes that need to be methylated (Young and Fairburn, 2000). The mRNA contents of the oocyte are related to the developmental competence of the zygote after fertilization (Lequarre et al., 1997). Furthermore, the length of the poly-A tail of RNA in bovine oocytes was to some extent correlated 
with the quality of the resulting blastocyst (Brevini-Gandolfi et al., 1999). The amounts of mRNA encoding for $\mathrm{Na}-\mathrm{K}-$ ATPase, $\mathrm{Cu}-\mathrm{Zn}$ superoxide dismutase (SOD), basic fibroblast growth factor (bFGF), cyclin A and B in bovine oocytes are affected by the maturation medium (Watson et al., 2000). The intrinsic quality of the oocyte is a key factor in determining blastocyst yields (Sirard and Blondin, 1996; Rizos et al., 2002). These findings indicate that prematuration and maturation of the oocyte affect patterns of gene expression at the blastocyst stage.

Various differences have been described between embryos derived in vitro and in vivo (Holm and Callesen, 1998; Niemann and Wrenzycki, 2000), including morphology (Van Soom and de Kruif, 1992; Van Soom et al., 1997a), number and allocation of cells (Van Soom et al., 1996; Viuff et al., 2001), frequency of apoptosis and mixoploidy (Viuff et al., 1999, 2001; Gjorret et al., 2001), tolerance to cryopreservation (Niemann, 1995; Enright et al., 2000), embryonic metabolism (Khurana and Niemann, 2000) and expression profile of specific mRNAs (Wrenzycki et al., 1996, 2001a; Eckert and Niemann, 1998; Lequarre et al., 2001). The relative abundance of several gene transcripts thought to be critically involved in preimplantation development is affected by the choice of basic culture medium and the type of protein supplement (Wrenzycki et al., 1999, 2001a). The effects of different maturational protocols on the relative abundance of genes important in development in blastocysts derived in vitro have not yet been investigated.

The aim of the present study was to determine the effects of prematuration-maturation (in vitro versus in vivo) of the oocyte on the relative abundance of a panel of six 'marker' genes important in development: glucose transporter 1, desmocollin 2, E-cadherin, plakophilin, heat shock protein 70.1 and poly(A) polymerase. These genes were selected because they are indicative of various mechanisms in preimplantation bovine development in vitro. Plakophilin and desmocollin 2 are of embryonic origin, whereas the other genes are of maternal and embryonic origin. All six transcripts are sensitive markers for compaction and cavitation, metabolism, RNA processing and stress susceptibility, and thereby indicate the quality of blastocysts (Wrenzycki et al., 1999, 2001a). The effects of different oocyte origins on blastocyst gene expression were investigated by collecting and analysing four groups of blastocysts from: (i) oocytes lacking the preovulatory development (in vitro group); (ii) oocytes prematured in vivo and matured in vitro (preLH group); (iii) oocytes prematured and matured in vivo (post-LH group); and (iv) blastocysts developed entirely in vivo (in vivo group). Oocytes derived from these different sources were subjected to in vitro fertilization and cultured to blastocysts in vitro under identical conditions.

\section{Materials and Methods}

\section{Experimental design}

Four groups of blastocysts that differed with regard to either the origin of the oocyte or conditions of embryo development were collected. In the first (in vitro) group, oocytes from ovaries obtained from an abattoir were matured, fertilized and cultured in vitro up to the blastocyst stage. In the second and third groups, two groups of cows were synchronized and treated with $\mathrm{FSH}$ to stimulate a large population of follicles to undergo the normal events of prematuration. The oocytes were collected either before the LH surge (pre-LH group) or $24 \mathrm{~h}$ after the induced LH surge (post-LH group). The oocytes from the pre-LH group were matured in vitro, and were then fertilized and cultured up to the blastocyst stage simultaneously with the oocytes from the post-LH group (Fig. 1). In the fourth (in vivo) group, blastocysts were collected from superovulated cows by flushing the uterus at day 7 after insemination. Oocytes and blastocysts were collected from Holstein Friesian cows. Oocytes were recovered from cows at a commercial abbatoir for the in vitro group, whereas donor animals from the experimental herd of the Veterinary Faculty of Utrecht University were used for the other three groups.

\section{Animals}

For the pre-LH $(n=8)$ and post-LH $(n=9)$ groups, 17 clinically healthy, non-lactating Holstein Friesian cows were selected on the basis of progesterone concentrations in peripheral blood samples measured three times a week for at least 4 weeks before the experiment. The cows were fed $20 \mathrm{~kg}$ corn silage and $4 \mathrm{~kg}$ concentrate per day, and grass silage and water were supplied ad libitum. The cows were presynchronized using an ear implant for 9 days (3 mg norgestomet, Crestar; Intervet International BV, Boxmeer), together with $3 \mathrm{mg}$ norgestomet and $5 \mathrm{mg}$ oestradiol valerate i.m. (Intervet International BV). Two days before the implant was removed, prostaglandin (15 mg Prosolvin i.m.; Intervet International BV) was administered.

On day 8 of the synchronized cycle (oestrus = day 0 ), all follicles $>5 \mathrm{~mm}$ were removed by transvaginal ultrasoundguided aspiration to avoid the inhibitory effects of follicular dominance on the developmental capacity of oocytes from subordinate follicles (Bungartz and Niemann, 1994). On day 9 of the oestrous cycle, the cows received another ear implant (3 mg norgestomet, Crestar) for 5 days, but no further combined norgestomet and oestradiol valerate. From day 10 of the oestrous cycle onwards, the cows received o-FSH i.m. (Ovagen $\mathrm{ICP}$, Auckland) twice a day in decreasing doses over 4 days $(3.5 \mathrm{ml}, 2.5 \mathrm{ml}, 1.5 \mathrm{ml}$ and $1.0 \mathrm{ml}$; in total $17 \mathrm{ml}$, equivalent to $299 \mathrm{iu} \mathrm{NIH-FSH-S1).}$ Prostaglandin (22.5 mg i.m.) was administered together with the fifth dose of $\mathrm{FSH}$, and $55 \mathrm{~h}$ later the ear implants were removed (Fig. 1).

The day after the last FSH dose, transrectal ultrasound technology was used to collect oocytes from cows with more than eight follicles $>8 \mathrm{~mm}$. For the pre-LH group, cows $(n=8)$ were ovariectomized $2 \mathrm{~h}$ after removal of the implant. In the post-LH group, cows $(n=9)$ received GnRH (1.0 mg Fertagyl in $10 \mathrm{ml}$ saline i.m.; Intervet International $\mathrm{BV}$ ) at the time of removal of the implant and were 


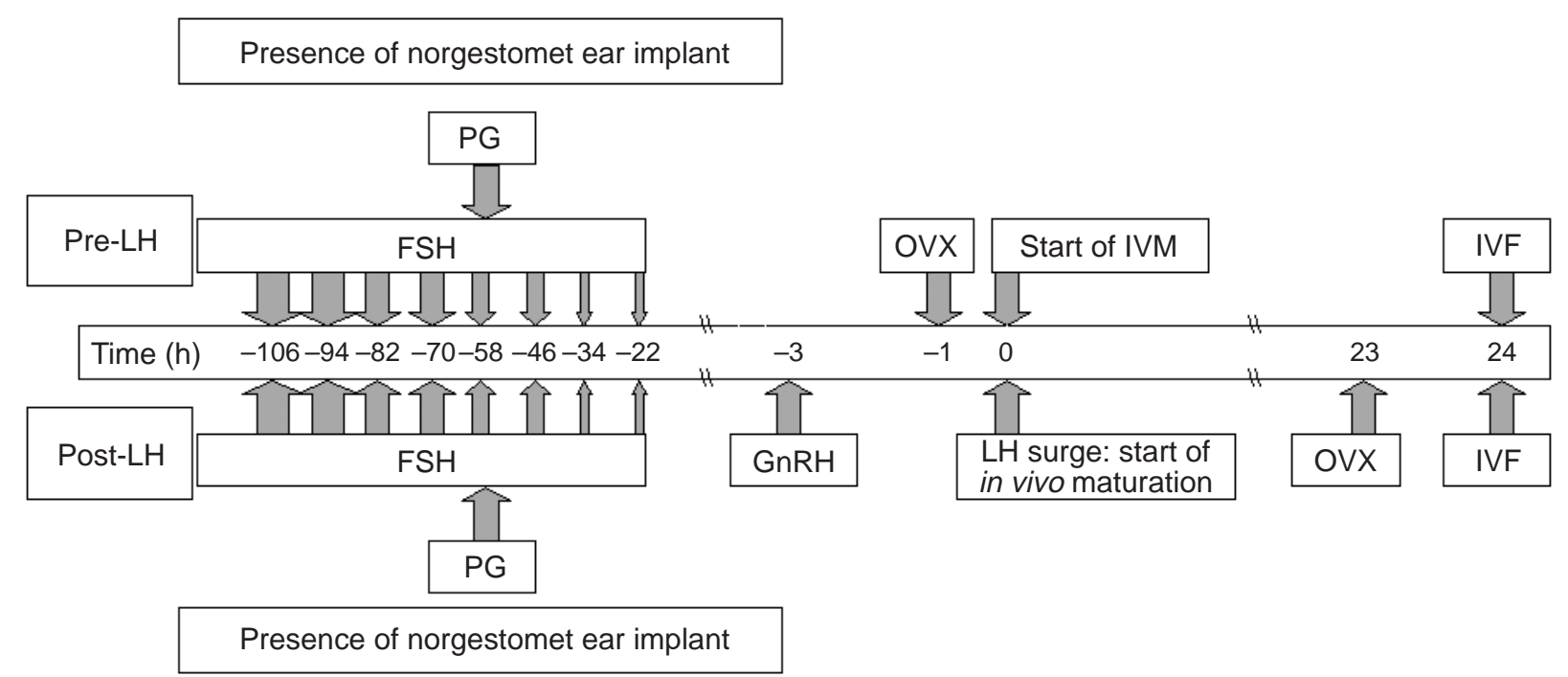

Fig. 1. Schedule of treatments for superovulation with a fixed LH surge to collect prematured oocytes from FSH-treated cows for in vitro maturation (pre-LH) or in vivo maturation (post-LH), and subsequent simultaneous in vitro fertilization (IVF). FSH: administration of eight consecutive, decreasing doses of FSH; time: the time relative to start of in vitro maturation (start of IVM); PG: administration of prostaglandin; $\mathrm{GnRH}$ : administration of $\mathrm{GnRH}$; $\mathrm{LH}$ surge: start of in vivo maturation: the time at which the maximum of the GnRH-induced LH surge occurs, starting in vivo maturation; OVX: ovariectomy.

ovariectomized $26 \mathrm{~h}$ after receiving GnRH. Ovariectomy was performed by laparotomy through a flank incision under local anaesthetic, using lidocaine cum adrenaline (Alfasan, Woerden). Ovaries were collected in $0.9 \%(\mathrm{w} / \mathrm{v})$ $\mathrm{NaCl}$ at $37^{\circ} \mathrm{C}$ and were immediately transported to the laboratory. Heparinized blood samples were collected from the jugular vein every day during the experimental cycle and every hour after removal of the second implant for $6 \mathrm{~h}$ or until ovariectomy. After immediate centrifugation at $1800 \mathrm{~g}$ for $10 \mathrm{~min}$ at $4^{\circ} \mathrm{C}$, plasma was stored at $-25^{\circ} \mathrm{C}$.

The seven cows in the in vivo group were treated with 3000 iu eCG (Intergonan; Intervet, Tönisvorst) between day 9 and day 13 of the oestrous cycle, and with prostaglandin (Estrumate; Schering-Plough, Munich) $48 \mathrm{~h}$ later. At oestrus, the donors were inseminated twice at an interval of $12 \mathrm{~h}$ with semen of a bull with proven fertility. At day 7 after insemination, blastocysts were recovered by non-surgical flushing of the uterine horns with $300 \mathrm{ml}$ PBS (Sigma, St Louis, $\mathrm{MO}$ ) supplemented with $1 \%$ newborn calf serum (NBCS, No. 295957; Boehringer, Mannheim) using established procedures.

Only blastocysts of morphological grades I and II (Robertson and Nelson, 1998) were included in this study. The blastocysts were stored in a minimum volume of PBS with $0.1 \%(\mathrm{w} / \mathrm{v})$ polyvinyl alcohol (PVA; Sigma) and stored at $-80^{\circ} \mathrm{C}$.

\section{Radioimmunoassays for progesterone and $\mathrm{LH}$}

Concentrations of progesterone in plasma were estimated by a solid-phase ${ }^{125}$ I-radioimmunoassay (Coat-ACount TKPG; Diagnostic Products Corporation, Los Angeles, CA) according to the instructions of the manufac- turer as validated by Dieleman and Bevers (1987). The sensitivity was $0.15 \mathrm{nmol} \mathrm{I}^{-1}$, and the intra- and interassay coefficients of variation were 8 and $<11 \%$, respectively.

Concentrations of $\mathrm{LH}$ in plasma were estimated by a validated homologous radioimmunoassay (Dieleman et al.,

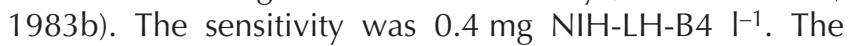
intra- and interassay coefficients of variation were $<9 \%$.

\section{Collection of oocytes and in vitro maturation}

In vitro group. Bovine ovaries were collected in a thermos flask at a local abbatoir from Holstein Friesian cows of unknown reproductive status and were then transported to the laboratory. Cumulus-oocyte complexes (COCs) were aspirated from 3-8 mm follicles, but only those with a multi-layered compact cumulus investment were used for the experiments. An average of ten usable COCs was collected per ovary. Selected COCs were rinsed once with Hepes-buffered M199 supplemented with 10\% fetal calf serum (FCS; Gibco BRL, Paisley) and once with maturation medium. Groups of 35 oocytes were randomly allocated to wells of four-well culture plates (Nunc A/S, Roskilde) containing $500 \mu \mathrm{l}$ maturation medium (M199; Gibco BRL) supplemented with 10\% FCS (Gibco BRL), 0.01 iu porcine $\mathrm{FSH} \mathrm{m}^{-1}$ (Sigma), and 0.01 iu equine $\mathrm{LH}$ $\mathrm{ml}^{-1}$ (Sigma) per well and then cultured for $22 \mathrm{~h}\left(39^{\circ} \mathrm{C}, 5 \%\right.$ $\mathrm{CO}_{2}$ in humidified air).

Pre-LH group. Immediately after ovariectomy, COCs were aspirated from putative preovulatory follicles $>8 \mathrm{~mm}$ and were included in the experiment on the basis of a minimum of three layers of compact cumulus investment. 
COCs of one cow were then processed in one well for in vitro maturation similar to the COCs of the in vitro group.

Post-LH group. Immediately after ovariectomy at $24 \mathrm{~h}$ after the $\mathrm{LH}$ surge, COCs matured in vivo were aspirated from preovulatory follicles $>8 \mathrm{~mm}$ and were selected for the experiment based on an expanded cumulus-cell mass. COCs with a compact cumulus investment and degenerated oocytes were discarded. Selected COCs from each cow were kept together in maturation medium in a single well until fertilization.

The interval between ovariectomy and transfer of COCs to maturation (pre-LH group) or fertilization (post-LH group) medium was 30-40 min. The duration of maturation was $24 \mathrm{~h}$ for the pre-LH group (in vitro) and $24 \mathrm{~h}$ in vivo (ovariectomy $24 \mathrm{~h}$ after the LH surge). Ovulation of fully matured oocytes occurs $24 \mathrm{~h}$ after the LH surge (Dieleman et al., 1983a). Maturation was assessed by determining expansion of the cumulus cells. Cytological studies have revealed that in our system $>80 \%$ of the oocytes reach the metaphase II stage.

\section{In vitro fertilization and embryo culture (IVF and IVC)}

Procedures for in vitro fertilization (IVF) were performed as described by Izadyar et al. (1996). In brief, matured oocytes of the in vitro, pre-LH and post-LH groups were fertilized in wells of four-well culture plates. All oocytes were fertilized at the same time with the same batch of semen from one bull with proven fertility. Before fertilization, oocytes in each well were rinsed twice with $2 \mathrm{ml}$ Hepes-buffered M199 medium.

Frozen-thawed semen used for IVF was centrifuged over a Percoll gradient for $30 \mathrm{~min}$ at $700 \mathrm{~g}$ at $25^{\circ} \mathrm{C}$. The sperm sample was collected by removing the gradient except for the last $150 \mu \mathrm{l}$ containing the sperm pellet. COCs were transferred to $0.43 \mathrm{ml}$ fertilization medium (Fert-TALP) (Parrish et al., 1988), but without glucose and with $10 \mu \mathrm{l}$ penicillin-streptomycin $\mathrm{ml}^{-1}$ (Gibco BRL) instead of gentamycin. Sperm suspension $(20 \mu \mathrm{l}$; final concentration $0.5 \times 10^{6}$ cells $\mathrm{ml}^{-1}$ ), $20 \mu \mathrm{l}$ heparin (final concentration $10 \mu \mathrm{l} \mathrm{ml}{ }^{-1}$; Sigma), and $20 \mu \mathrm{l} \mathrm{PHE} \mathrm{(consisting} \mathrm{of} 20 \mu \mathrm{mol}$ D-penicillamine $\mathrm{I}^{-1}, 10 \mu \mathrm{mol}$ hypotaurine $\mathrm{I}^{-1}, 1 \mu \mathrm{mol}$ adrenaline $\mathrm{I}^{-1}$; Sigma) were added to the fertilization medium. After $18-20 \mathrm{~h}$ of incubation at $39^{\circ} \mathrm{C}$, with $5 \% \mathrm{CO}_{2}$ in humidified air, cumulus cells were completely removed from presumptive zygotes by vortexing for $3 \mathrm{~min}$; a maximum of ten zygotes was placed in $20 \mu \mathrm{l}$ droplets of synthetic oviductal fluid (SOF) medium under oil (Squibbs Oil, Princeton, NJ) (Van Wagtendonk-de-Leeuw et al., 2000). Zygotes of the pre-LH and post-LH groups from each animal were cultured in individual droplets. In vitro culture (IVC) was performed at $39^{\circ} \mathrm{C}$ in a humidified atmosphere containing $5 \% \mathrm{CO}_{2}, 7 \% \mathrm{O}_{2}$ and $88 \% \mathrm{~N}_{2}$. On day 4 of culture, all cleavage stages were transferred to fresh culture droplets, and the proportion of each cleavage stage was assessed. On day 7 after insemination, blastocysts and expanded blastocysts were collected, whereas morulae and early blastocysts were cultured for one additional day. On day 8, additional blastocysts and expanded blastocysts were collected. Day 1 of culture was defined as beginning immediately after completion of IVF. Embryos were washed four times in PBS with $0.1 \%$ (w/v) PVA (PBS-ET; Bio Whittaker Europe, Verviers) and transferred to $0.5 \mathrm{ml}$ cups in a minimum volume $(\leqslant 5 \mu \mathrm{l})$ of PBS with $0.1 \%(\mathrm{w} / \mathrm{v})$ PVA and frozen at $-80^{\circ} \mathrm{C}$. Analysis of cultured embryos was confined to those of morphological grades I and II (Robertson and Nelson, 1998).

\section{Selection of the embryos for RT-PCR}

For each gene, embryos from as many different cows as possible were analysed. Furthermore, similar numbers of embryos collected on days 7 and 8 were assigned to each mRNA analysis. Depending on the type of gene, four to five transcripts were analysed per embryo and at least five embryos per gene were determined. The relative abundance of mRNAs from the six different genes important in the development of a preimplantation embryo was determined in single bovine blastocysts by semi-quantitative RT-PCR.

\section{Isolation of RNA}

Poly $(\mathrm{A})^{+}$RNA from a single embryo was isolated using a Dynabeads mRNA DIRECT kit (Dynal A.S., Oslo). RNA was isolated following the manufacturer's instructions with minor alterations (Wrenzycki et al., 1999). In brief, frozen embryos were thawed by adding $30 \mu$ lysis buffer (100 mmol Tris-HCl I-1, pH 7.5; 500 mmol LiCl I-1; 10 mmol EDTA I-1, pH 8; 1\% (w/v) LiDS (SDS); $5 \mathrm{mmol}$ dithiothreitol ${ }^{-1}$ ). As an internal standard, $1.0 \mathrm{pg}$ rabbit globin RNA (Life Technologies BV, Eggenstein) was added to each embryo. The samples were mixed for $10 \mathrm{~s}$, centrifuged for $15 \mathrm{~s}$ at $12000 \mathrm{~g}$, and left for $10 \mathrm{~min}$ at room temperature. Dynabeads ( $5 \mu \mathrm{l}$; Dynal) were added and mixed for $5 \mathrm{~min}$ at room temperature. The samples were put in the magnetic separator to remove the lysis buffer and leave the Dynabeads. The Dynabeads were washed four times, once with $40 \mu \mathrm{l}$ washing buffer A (10 mmol Tris- $\mathrm{HCl}$ $\mathrm{I}^{-1}$, pH 7.5; $0.15 \mathrm{~mol} \mathrm{LiCl} \mathrm{I}^{-1} ; 1.0 \mathrm{mmol}$ EDTA I-1; $0.1 \%$ $(\mathrm{w} / \mathrm{v})$ LiDS) and three times with $40 \mu \mathrm{l}$ washing buffer B (10 mmol Tris- $\mathrm{HCl} \mathrm{I}^{-1}$, $\mathrm{pH} 7.5 ; 0.15 \mathrm{~mol} \mathrm{LiCl} \mathrm{I-1;} 1.0 \mathrm{mmol}$ EDTA $~^{-1}$ ). After removal of washing buffer $\mathrm{B}, 11 \mu \mathrm{l}$ sterile $\mathrm{H}_{2} \mathrm{O}$ was added and incubated at $65^{\circ} \mathrm{C}$ for 2 min to elute mRNA from the Dynabeads. The cups were put into the magnetic separator again; the supernatant was removed and immediately used for reverse transcription.

\section{Reverse transcription}

Poly $(\mathrm{A})^{+}$RNA isolated from a single embryo was reverse transcribed into cDNA in a total volume of $20 \mu \mathrm{l}$. The reaction mixture consisted of $1 \times \mathrm{RT}$ buffer $(50 \mathrm{mmol} \mathrm{KCl}$ $\mathrm{I}^{-1} ; 10$ mmol Tris-HCl ${ }^{-1}, \mathrm{pH}$ 8.3; Perkin Elmer Biosystems, Vaterstatten), $5 \mathrm{mmol} \mathrm{MgCl}_{2} \mathrm{I}^{-1}, 1 \mathrm{mmol}$ of each dNTP $\mathrm{I}^{-1}$ (Amersham, Brunswick), $2.5 \mu \mathrm{mol}$ random hexamers $\mathrm{I}^{-1}$ (Perkin Elmer), 20 iu RNase inhibitor (Perkin Elmer) and 
50 iu MuLV reverse transcriptase (Perkin Elmer). The samples were centrifuged for $15 \mathrm{~s}$ at $12000 \boldsymbol{g}$ and were overlaid with mineral oil to prevent evaporation. One sample was prepared with $1.0 \mathrm{pg}$ rabbit globin RNA and $10 \mu \mathrm{l} \mathrm{H}_{2} \mathrm{O}$. As negative controls, tubes without an RNA sample and tubes with an RNA sample, but without reverse transcriptase, were analysed. The reverse transcription reaction was carried out in a thermocycler (Biometra Triothermoblock; Biometra, Göttingen) for $10 \mathrm{~min}$ at $25^{\circ} \mathrm{C}$, 60 min at $42^{\circ} \mathrm{C}$, and $5 \mathrm{~min}$ at $99^{\circ} \mathrm{C}$, and was kept on ice once the reaction was completed.

\section{PCR}

Immediately after reverse transcription the samples were subjected to PCR amplification. PCR was performed with a volume of the reverse transcriptase reaction corresponding to 0.1 (desmocollin 2 and Glut-1), 0.2 (heat shock protein, E-cadherin and poly(A) polymerase) and 0.4 (plakophilin) embryo equivalents in a final volume of $50 \mu \mathrm{l}$, containing $1 \times$ PCR buffer $\left(20 \mathrm{mmol}^{\mathrm{T} i s}-\mathrm{HCl} \mathrm{I}^{-1} ; 50 \mathrm{mmol} \mathrm{KCl} \mathrm{I}^{-1}, \mathrm{pH}\right.$ 8.4; Life Technologies), $1.5 \mathrm{mmol} \mathrm{MgCl}_{2} \mathrm{I}^{-1}, 200 \mu \mathrm{mol}$ of each dNTP $\mathrm{I}^{-1}$ and $1 \mu \mathrm{mol}$ of each sequence-specific primer

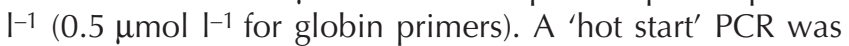
performed to obtain specific amplification. During the hot start' 1 iu Taq DNA polymerase (Life Technologies) was added at $72^{\circ} \mathrm{C}$. The sequences and positions of the primers used, the annealing temperature, the fragment sizes of the expected products and the sequence references are shown (Table 1). The products of each primer pair were sequenced to confirm the identity of the RT-PCR fragments.

Running a linear cycle series established the optimal cycle number at which the transcript was amplified exponentially for the PCR reaction. The PCR programme started at $97^{\circ} \mathrm{C}$ for $2 \mathrm{~min}$, decreased to $72^{\circ} \mathrm{C}$ for $2 \mathrm{~min}$ (hot start) and was followed by a number of cycles, which depended on the gene (Table 1), of $15 \mathrm{~s}$ at $95^{\circ} \mathrm{C}$ for denaturation, $15 \mathrm{~s}$ at the annealing temperature of the specific gene (Table 1) and $15 \mathrm{~s}$ at $72^{\circ} \mathrm{C}$ for primer extension. After finishing these cycles a final extension of 5 min at $72^{\circ} \mathrm{C}$ was performed, followed by cooling to $4^{\circ} \mathrm{C}$. A PTC-200 thermocycler (MJ Research, Watertown, MA) was used.

\section{Detection and semi-quantification of RT-PCR products}

RT-PCR product $(25 \mu \mathrm{l})$ with $5 \mu \mathrm{l}$ of $10 \times$ loading buffer $\left(0.25 \%(\mathrm{w} / \mathrm{v})\right.$ xylenecyanol and $25 \mathrm{mmol}^{\mathrm{E}}$ EDA $\mathrm{I}^{-1}$ in $50 \%$ $(\mathrm{w} / \mathrm{v})$ glycerin) was loaded on to a $2 \%(\mathrm{w} / \mathrm{v})$ agarose gel in

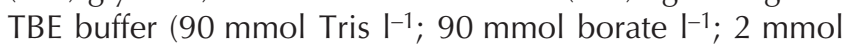
EDTA $^{-1}$, pH 8.3) containing $0.2 \mu$ g ethidium bromide $\mathrm{ml}^{-1}$ and subjected to electrophoresis. The concentration of ethidium bromide in the running buffer and the gel was the same. After electrophoresis at $100 \mathrm{~V}$ for $5 \mathrm{~min}$ and at $80 \mathrm{~V}$ for $40 \mathrm{~min}$, the fragments were visualised on a $312 \mathrm{~nm}$ UV transilluminator. A CCD camera (Quantix; Photometrics, Munich) and IP Lab spectrum (IP Lab Gel; Signal Analytics Corporation, Vienna, VA) were used to digitize the image of

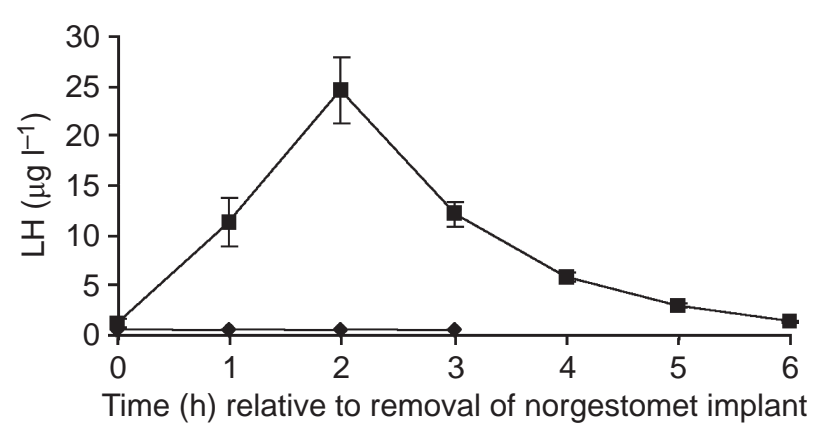

Fig. 2. Concentration (mean $\pm S E M$ ) of $L H$ in peripheral blood of $\mathrm{FSH}$-prostaglandin-norgestomet-treated cows without $\mathrm{GnRH}$ (pre$\mathrm{LH}, n=8 ; \bullet$ ) and with GnRH administered (post-LH, $n=7 ; \mathbf{\square}$ ); $\mathrm{GnRH}$ was administered at the time of removal of the implant.

the gel. Densitometric scanning using a computer-assisted image analysis system (IP Lab Gel; Signal) was used to quantify the signal intensity of each band. The relative abundance of the mRNA of the different genes was estimated by dividing the intensity of the band of the gene of interest by the intensity of the globin band from the same sample.

The recovery rate of the RNA was estimated for all of the embryos. It was calculated as the ratio between the intensity of the globin bands with and without RNA extraction. On average, $42 \%$ of the poly $(\mathrm{A})^{+}$RNA of the blastocyst was extracted, which is similar to percentages obtained by Wrenzycki et al. (1999).

\section{Statistical analysis}

Rates of blastocyst formation were analysed with logistic regression and $P \leqslant 0.05$ was considered significant. For the relative abundance of the gene transcripts, an analysis of variance was performed using the nlme library of S-PLUS 2000 with random cow effects (Pinheiro and Bates, 2000). Data are presented as mean \pm SEM.

\section{Results}

Response to superovulation treatment (pre-LH and postLH groups)

No LH surge was observed in peripheral blood of cows in the pre-LH group (Fig. 2). The cows that were treated with $\mathrm{GnRH}$ (post-LH group) showed a clear LH surge at $2 \mathrm{~h}$ after the administration of $\mathrm{GnRH}$; in cows from which embryos were collected for RT-PCR, maximum LH concentration was $24.5 \pm 2.5 \mu \mathrm{g} \mathrm{I}^{-1}$ ( $n=7$; Fig. 2 ).

Signs that an LH surge had occurred before the implant was removed were observed in four cows: cumulus cells were moderately expanded in two cows from the pre-LH group and two cows of the post-LH group had already ovulated. Oocytes from these animals were excluded from the experiment.

The superovulation response in the pre-LH and the 
Table 1. Primers used for PCR

\begin{tabular}{|c|c|c|c|c|c|}
\hline Genes & Primer sequence and positions & $\begin{array}{l}\text { Number of } \\
\text { cycles }\end{array}$ & $\begin{array}{c}\text { Annealing } \\
\text { temperature }\left({ }^{\circ} \mathrm{C}\right)\end{array}$ & $\begin{array}{l}\text { Fragment } \\
\text { size (bp) }\end{array}$ & $\begin{array}{l}\text { Sequence } \\
\text { references (EMBL } \\
\text { accession number) }\end{array}$ \\
\hline Globin & $\begin{array}{l}\text { 5' primer (241-260): } \\
\text { GCAGCCACGGTGGCGAGTAT } \\
\text { 3' primer (555-657): } \\
\text { GTGGGACAGGAGCTTGAAAT }\end{array}$ & 27 & 60 & 257 & $\begin{array}{l}\text { Cheng et al. (1986) } \\
\text { (X04751) }\end{array}$ \\
\hline Desmocollin 2 & $\begin{array}{l}\text { 5' primer (2085-2109): } \\
\text { CTCCTGGCGATGACAAAGT } \\
\text { GTATTC } \\
\text { 3' primer (2503-2527): } \\
\text { GCCGATCCTCTTCCTTCGTA } \\
\text { GTTAT }\end{array}$ & 31 & 57 & $\begin{array}{l}443 / 397 \\
\text { (insertion } \\
\text { of } 46 \mathrm{bp}, \\
2396-2441 \text { ) }\end{array}$ & $\begin{array}{l}\text { Koch et al. (1992) } \\
\text { (M81190) }\end{array}$ \\
\hline Plakophilin & $\begin{array}{l}\text { 5' primer (1337-1361): } \\
\text { CCCGTGGACCCCGAGGTCTT } \\
\text { CTTCA } \\
\text { 3' primer (1580-1604): } \\
\text { CGGTGTAGGCGTTGCGGGCG } \\
\text { TTGTAACTCTGGCTGATAAAA }\end{array}$ & 35 & 64 & 268 & $\begin{array}{l}\text { Heid et al. (1994) } \\
\text { (Z37975) }\end{array}$ \\
\hline Glucose transporter 1 & $\begin{array}{l}\text { 5' primer (1609-1638): } \\
\text { AGGAGCTGTTCCACCСССTG } \\
\text { GGAGCTGACT } \\
\text { 3' primer (1906-1935): } \\
\text { TGTGGGTGAAGGAG }\end{array}$ & 32 & 59 & 327 & $\begin{array}{l}\text { Boado and Pardridge } \\
\text { (1991) (M60448) }\end{array}$ \\
\hline Poly(A) polymerase & $\begin{array}{l}\text { 5' primer (886-915): } \\
\text { GTTTCCTCGGTGGTGTTTCC } \\
\text { TGGGCTATGC } \\
\text { 3' primer (1108-1137): } \\
\text { TGGAGTTCTGTTGTGGGTAT } \\
\text { GCTGGTGTAA }\end{array}$ & 35 & 57 & 252 & $\begin{array}{l}\text { Raabe et al. (1991) } \\
\text { (X63436) }\end{array}$ \\
\hline Heat shock protein 70.1 & $\begin{array}{l}\text { 5' primer (1861-1890): } \\
\text { AAGGTGCTGGACAAGTGCC } \\
\text { AGGAGGTGATT } \\
\text { 3' primer (2319-2348): } \\
\text { ACTTGGAAGTAAACAGAAA } \\
\text { CGGGTGAAAAA }\end{array}$ & 36 & 59 & 488 & $\begin{array}{l}\text { Gutierrez and } \\
\text { Guerrioro (1995) } \\
\text { (U09861) }\end{array}$ \\
\hline E-cadherin & $\begin{array}{l}\text { 5' primer (1486-1515): } \\
\text { CTCAAGCTCGCGGATAACC } \\
\text { AGAACAAAGAC } \\
\text { 3' primer (1785-1814): } \\
\text { AGGCCCCTGTGCAGCTGGC } \\
\text { TAAATCAAAG }\end{array}$ & 33 & 55 & 332 & $\begin{array}{l}\text { Ringwald et al. } \\
\text { (1987) (X06339) }\end{array}$ \\
\hline
\end{tabular}

post-LH groups was $30.3 \pm 10.5$ (mean \pm SD, $n=6$ ) and $23.1 \pm 10.0$ (mean $\pm \mathrm{SD}, n=7$ ) follicles $>8 \mathrm{~mm}$ on average per cow, respectively.

\section{Oocyte recovery and in vitro culture}

In the pre-LH group, 166 COCs were collected from 182 follicles of preovulatory size from six cows (recovery rate $91.2 \%$ ). COCs that did not have an intact multi-layered compact cumulus investment or that already showed cumulus expansion were excluded $(n=26)$ from analysis. In the post-LH group, 136 oocytes were collected from 162 follicles of preovulatory size from seven cows (recovery rate $84.0 \%$ ). Denuded oocytes and COCs not showing cumulus expansion $(n=20)$ were excluded. In the in vitro group, 333 oocytes were collected and used for IVM, IVF and IVC.

Cleavage rates on day 4 of culture were similar in the three IVC groups (average 75\%; Table 2). On day 7 after 
Table 2. Rates of blastocyst formation after in vitro culture (IVC) and IVF of in vivo- or in vitro-matured oocytes obtained from preovulatory follicles from $\mathrm{FSH}$-stimulated cows compared with the rates of in vitro-matured oocytes from 3-8 mm follicles

\begin{tabular}{|c|c|c|c|c|c|}
\hline & \multirow{2}{*}{$\begin{array}{l}\text { Number of oocytes } \\
\text { after IVF, day } 1^{*}\end{array}$} & \multirow{2}{*}{$\begin{array}{c}\text { Number of cleaved } \\
\text { embryos on day } 5(\%)\end{array}$} & \multicolumn{3}{|c|}{ Number of blastocysts } \\
\hline & & & Day $7^{+}(\%)$ & Day 8 (\%) & Total \\
\hline \multicolumn{6}{|l|}{ Preovulatory follicles } \\
\hline Pre-LH (after in vitro maturation) & 140 & $123(87.9)$ & $51(36.4)^{\mathrm{a}}$ & $19(13.6)^{\mathrm{a}}$ & $70(50.0)^{\mathrm{a}}$ \\
\hline Post-LH (after in vivo maturation) & 116 & $85(73.3)$ & $29(25.0)^{b}$ & $7(6.0)^{\mathrm{a}}$ & $36(31.0)^{b}$ \\
\hline \multicolumn{6}{|l|}{ 3-8 mm follicles } \\
\hline After IVM & 333 & $233(70.0)$ & $55(16.5)^{\mathrm{c}}$ & $33(9.9)^{\mathrm{a}}$ & $88(26.4)^{\mathrm{b}}$ \\
\hline
\end{tabular}

*Oocytes were collected from preovulatory follicles before (pre-LH) or $24 \mathrm{~h}$ after (post-LH) an induced LH surge. Day 1 is start of IVC. Percentages of cleavage and blastocyst formation are calculated relative to the number of (non)-fertilized oocytes at day 1 of IVC.

${ }^{\dagger}$ At day 7 of IVC, blastocysts were collected and stored for RT-PCR, and morulae and early blastocysts were cultured for an additional day and collected as blastocysts at day 8 .

a-c Values with different superscripts within a column are significantly different $(P<0.05)$.

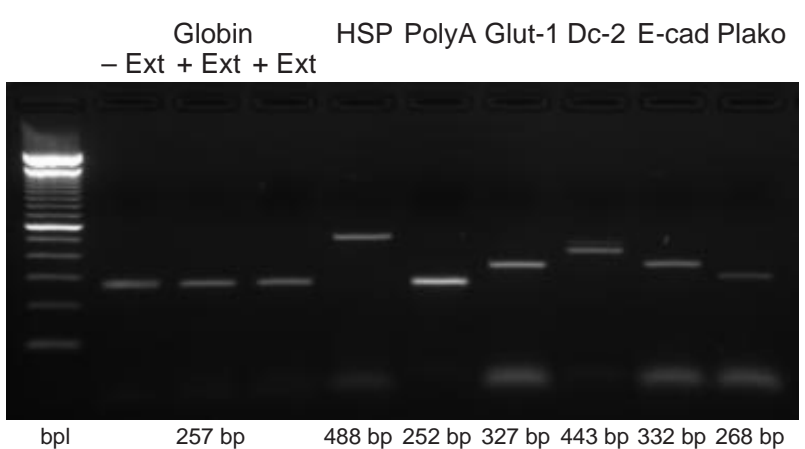

Fig. 3. Expression of six genes important to development as detected by RT-PCR in a 0.1 to 0.4 proportion of a single bovine blastocyst; digitalized image after electrophoresis on an agarose gel containing ethidium bromide. PCR products are indicated at the top for heat shock protein $70.1(\mathrm{HSP})$, poly $(\mathrm{A})$ polymerase (polyA), glucose transporter 1 (Glut-1), desmocollin 2 (Dc-2), Ecadherin (E-cad) and plakophilin (plako), and for the RNA extraction control globin (- Ext: without extraction; + Ext: with extraction). Expected fragment sizes are indicated at the bottom; bpl: 100 bp ladder as marker for fragment size.

insemination, most (60-80\%) of the blastocysts had already formed. Rates of blastocyst formation at day 7 were significantly $(P<0.05)$ different in the pre-LH, post- $\mathrm{LH}$ and in vitro groups. The overall rate of blastocyst formation was significantly $(P<0.05)$ higher in the pre-LH group $(50 \%$; Table 2) than in the post-LH (31.0\%) and in vitro groups $(26.4 \%)$. Most of the blastocysts in the three IVC groups were already expanded: $64.3,52.7$ and $54.5 \%$ for pre-LH, post-LH and in vitro group embryos, respectively.

\section{Relative abundance of genes in single blastocysts derived from different oocyte origins}

For RT-PCR products (Fig. 3), the bands represent gene transcripts derived from $0.1-0.4$ parts of a bovine blastocyst. As negative controls, RNA or reverse transcriptase was
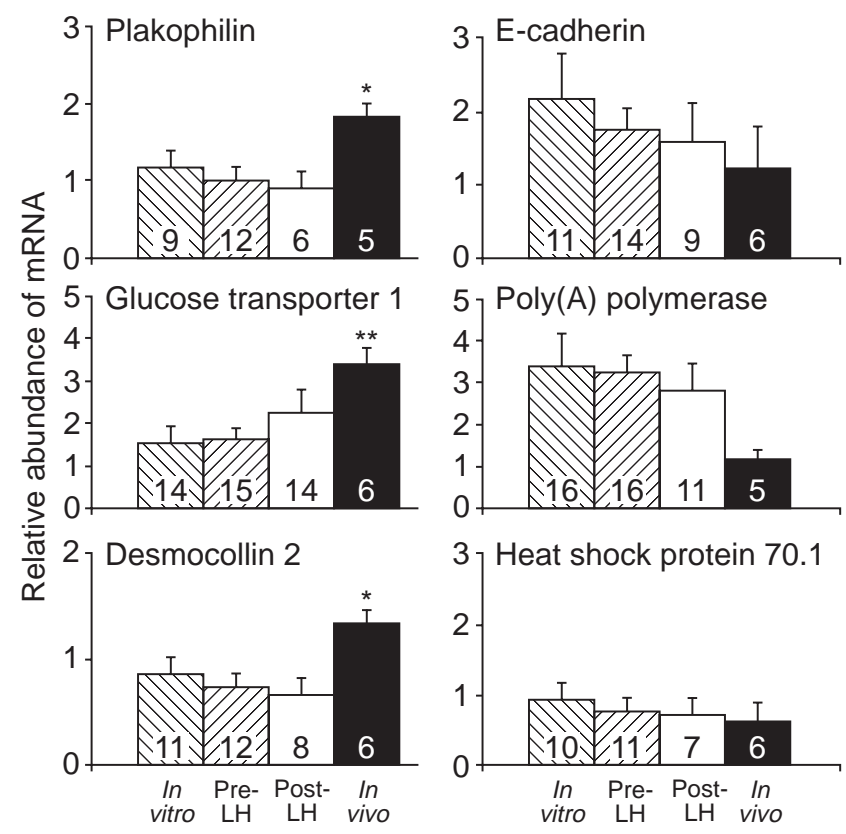

Fig. 4. Relative abundance of transcripts of six genes important to development as detected by semi-quantitative RT-PCR in single bovine blastocysts originating from oocytes subjected to different modes of maturation. Embryos were derived from: (i) immature oocytes from 3-8 mm follicles after IVM, IVF and IVC (in vitro group; $\nabla$ ); (ii) prematured oocytes from preovulatory sized, $\mathrm{FSH}$ stimulated follicles after IVM, IVF and IVC (pre-LH group; $\square$ ); (iii) prematured oocytes from preovulatory sized, FSH-stimulated follicles after in vivo maturation, IVF and IVC (post-LH group; $\square$ ); and (iv) similar oocytes to those in (iii) but also with fertilization and development entirely in vivo (in vivo group; $\mathbf{0}$ ). Bars represent the mean \pm SEM relative abundance of a number of blastocysts as indicated in the bars; each value was the mean of at least five different cows. Asterisks indicate difference from all groups: $* P<0.1 ;{ }^{* *} P<0.05$.

omitted during the reverse transcription reaction. No amplified products were found at any time in the negative controls during these experiments. 
The relative abundance of Glut-1 was significantly $(P<0.05)$ higher in the in vivo group compared with the pre-LH, post-LH and in vitro groups (Fig. 4). The relative abundance of desmocollin 2 and plakophilin tended to be higher in the fourth group (in vivo) compared with the other three groups, although this difference was not significant. No significant differences were detected in any of the gene transcripts between the three in vitro groups (in vitro, preLH and post-LH groups; Fig. 4).

\section{Discussion}

In the present study the effects of different maturation regimens of bovine oocytes on the relative abundance of transcripts from six genes important in development in blastocysts were investigated. In vitro conditions have profound effects on the patterns of expression of a range of gene transcripts in bovine and murine embryos (Ho et al., 1994, 1995; Niemann and Wrenzycki, 2000). The present data show for the first time that prematuration-maturation does not necessarily affect the relative abundance of the genes and indicate that in vitro maturation may not be the critical factor contributing to variation in mRNA content between in vitro- and in vivo-derived embryos. The differences between in vivo- and in vitro-derived blastocysts were probably not due to variation in the rates of development. In parallel experiments, blastocysts derived in vivo and in vitro as well as those derived from pre-LH and post-LH groups had similar numbers of cells.

The semi-quantitative RT-PCR assay used in the present study provides sensitive and highly reproducible results from both pooled and single bovine embryos. It has constantly been updated and increased in sensitivity (Wrenzycki et al., 1999, 2001a,b, 2002). The validity of the assay has been demonstrated previously and revealed efficient amplification of both the globin standard and the RNA of choice (Wrenzycki et al., 2000). Its accuracy compares favourably with current real-time RT-PCR techniques (Stenman et al., 1999). Similar to endpoint RT-PCR, real-time RT-PCR uses standards against which the amounts of mRNA of the genes of choice are compared (Freeman et al., 1999; Bustin, 2000; Steuerwald et al., 2000). The densitometric analysis of ethidium bromidestained agarose gels described in the present study is a well established and sensitive enough approach to detect even subtle differences in amounts of mRNA in different biological materials (Grover et al., 2001; Ringhoffer et al., 2001). The degree of variation with this approach is rather small (Grover et al., 2001), but can be further decreased by an optimized real-time RT-PCR protocol (Bustin, 2000). We have calculated the number of replicates necessary to obtain statistically significant differences to accommodate any inherent variability. This approach has recently proven valid for single bovine cloned and IVP embryos (Wrenzycki et al., 2001b, 2002). The differences in patterns of expression described previously were related to the increased incidence of the large offspring syndrome in offspring derived from IVP or cloned bovine embryos (Niemann and Wrenzycki, 2000; Niemann et al., 2002). Even subtle changes in patterns of expression of specific genes were shown to have marked biological effects such as predisposition to tumourigenesis (Yan et al., 2002) and may be causally involved in large offspring syndrome.

The mRNAs measured in blastocysts in the present study were probably transcribed during embryonic development and did not represent mRNAs that remained from the maternal mRNA pool. Plakophilin, desmocollin 2 and Ecadherin are predominantly expressed from the morula stage onwards (Wrenzycki et al., 1999, 2001a). The mRNAs of glucose transporter 1 and poly(A) polymerase were found throughout early development up to the blastocyst stage, which is indicative of both maternal and embryonic origin, with a burst after maternal-embryonic transition of genomic activity (Wrenzycki et al., 1999). The different amounts of mRNA observed in blastocysts derived from oocytes matured in vitro or in vivo in the present study are supported by findings from histological and biochemical studies. Embryos developed in vitro frequently form the blastocoel earlier than in vivo, without proper compaction, and have fewer cells than do in vivo-grown embryos (Van Soom et al., 1997b). Desmocollin 2 and plakophilin molecules are involved in intercellular communication structures and compaction (Collins et al., 1995). The lower expression of desmocollin 2 and plakophilin observed in blastocysts of the in vitro group might explain the impaired compaction in embryos produced in vitro. Differences in metabolism between bovine embryos produced in vitro and those developed in vivo have been detected, especially with regard to lactate production and glucose metabolism (Khurana and Niemann, 2000). The decreased amount of glucose transporter 1 in in vitro embryos found in the present study probably reflects differences in energy metabolism between blastocysts developed in vitro and in vivo.

A novel aspect of the present study was related to expression of the panel of genes in blastocysts derived from prematured oocytes (pre-LH group) and oocytes matured in vivo (post-LH group). The results of the present study indicate that blastocysts developed from pre-LH and postLH oocytes are not different with respect to patterns of gene expression from those derived from oocytes that lacked a period of prematuration and in vivo maturation. Nevertheless, the mode of oocyte prematuration and maturation may affect the developmental competence after cleavage into morulae and blastocysts (Hyttel et al., 1997).

The rate of blastocyst development in the pre-LH group was higher than in the in vitro group, which is in accordance with earlier observations and confirms the stimulatory effects of prematuration on oocyte developmental competence. The rate of blastocyst development in the post-LH group differed from recent findings in which exceptionally high rates of blastocyst development were found (Van de Leemput et al., 1999; Hendriksen et al., 2000). When two cows with low rates of blastocyst development were excluded from analysis, the rate of 
blastocyst development of the post-LH group increased to approximately $45 \%$ and the relative abundance of the genes did not change significantly. The high proportion of wellexpanded blastocysts indicates the inherent high capacity of the blastocysts for development.

The results of the present study indicate that in vitro maturation - as the first step in IVP of embryos - has improved significantly (Bavister, 1995; Keskintepe and Brackett, 1996). Blastocysts derived from oocytes that were matured differently, but cultured identically, did not show significant differences with respect to the panel of gene transcripts investigated in the present study. The differences may therefore be related to the in vitro conditions imposed on fertilized oocytes. This contention is supported by previous findings for sheep and cattle, in which zygotes were subjected to different culture conditions and developed abnormal phenotypes (Young et al., 1998; Sinclair et al., 2000). Nevertheless, it could be useful to analyse gene expression in oocytes immediately after completing different maturation protocols. However, this would require a different panel of gene transcripts to be informative, including genes involved in cell cycle regulation, meiotic competence and cumulus expansion. Little is known about transcriptional activity in bovine oocytes. Duration of oocyte maturation and quality of COCs affected transcription of cyclooxygenase-2 and various prostaglandin $\mathrm{E}$ receptors in in vitro culture (Calder et al., 2001). Furthermore, it would be interesting to determine rates of transcription in the embryos in which development was arrested at an early stage and thus did not reach the blastocyst stage.

In conclusion, the difference in the relative abundance of the six gene transcripts found between blastocysts produced in vitro and in vivo can probably be attributed to embryo culture conditions after maturation and fertilization. Prematuration and maturation are thought to be critically involved in the ability of the oocyte to support early development (Sirard and Blondin, 1996; Hyttel et al., 1997; Rizos et al., 2002). Whether blastocysts derived from oocytes matured in vivo or in vitro differ with regard to quality has yet to be determined. It should be noted that this study was limited to a panel of six gene transcripts and it is possible that other gene transcripts would behave differently. cDNA array technology enables simultaneous determination of a potentially unlimited number of gene transcripts and it has already been applied to the diagnosis of various forms of human cancer, human autoimmune diseases and the characterization of murine embryonic stem cells (Alizadeh et al., 2000; Kelly and Rizzino, 2000; Rogge et al., 2000). A prototype of a suitable cDNA array for single bovine embryos has recently become available (Brambrink et al., 2002) and its broader application will also improve determination of patterns of gene expression in embryos derived from IVP or cloning.

The authors thank D. M. Blankenstein, E. C. Zeinstra and S. Wilkening for technical assistance, and animal handlers and surgery assistants for management of the animals. The authors also gratefully acknowledge J. van de Broek and J. C. M. Vernooy for advice on statistical analysis.

\section{References}

Alizadeh AA, Eisen MB, Davis RE et al. (2000) Distinct types of diffuse B-cell lymphoma identified by gene expression profiling Nature 403 503-511

Assey RJ, Hyttel P, Greve T and Purwantara B (1994) Oocyte morphology in dominant and subordinate follicles Molecular Reproduction and Development 37 335-344

Bavister BD (1995) Culture of preimplantation embryos: facts and artifacts Human Reproduction Update 191-148

Blondin P, Coenen K, Guilbault LA and Sirard MA (1997) In vitro production of bovine embryos: developmental competence is acquired before maturation Theriogenology 47 1061-1075

Boado RJ and Pardridge WM (1991) Molecular cloning of the bovine blood-brain barrier transporter CDNA and demonstration of phylogenetic conservation of the $5^{\prime}$ untranslated region Molecular and Cellular Neurosciences 1 224-232

Brambrink T, Wabnitz P, Halter R, Lucas-Hahn A, Kues WA, Carnwath JW, Wrenzycki C, Paul D and Niemann H (2002) Expression profiling of single preimplantation embryos using CDNA array analysis Theriogenology 57633 (Abstract)

Brevini-Gandolfi TAL, Favetta LA, Mauri L, Luciano AM, Cillo F and Gandolfi F (1999) Changes in poly(A) tail length of maternal transcripts during in vitro maturation of bovine oocytes and their relation with developmental competence Molecular Reproduction and Development 52 427-433

Bungartz L and Niemann H (1994) Assessment of the presence of a dominant follicle and selection of dairy cows suitable for superovulation by single ultrasound examination Journal of Reproduction and Fertility $101583-591$

Bustin SA (2000) Absolute quantification of mRNA using real-time reverse transcription polymerase chain reaction assays Journal of Molecular Endocrinology 25 169-193

Calder MD, Caveney AN, Westhusin ME and Watson AJ (2001) Cyclooxygenase-2 and prostaglandin $\mathrm{E}_{2}\left(\mathrm{PGE}_{2}\right)$ receptor messenger RNAs are affected by bovine oocyte maturation time and cumulusoocyte complex quality, and $\mathrm{PGE}_{2}$ induces moderate expansion of the bovine cumulus in vitro. Biology of Reproduction 65 135-140

Cheng JF, Raid L and Hardison RC (1986) Isolation and nucleotide sequence of the rabbit globin gene cluster psi zeta-alpha 1-psi alpha. Absence of a pair of alpha-globin genes evolving in concert Journal of Biological Chemistry 261 839-848

Collins JE, Lorimer JE, Garrod DR, Pidsley SC, Buxton RS and Fleming TP (1995) Regulation of desmocollin transcription in mouse preimplantation embryos Development 121 743-752

Dieleman SJ and Bevers MM (1987) Effects of monoclonal antibody against PMSG administered shortly after the preovulatory LH surge on time and number of ovulations in PMSG/PG-treated cows Journal of Reproduction and Fertility 81 533-542

Dieleman SJ, Kruip TA, Fontijne P, de Jong WHR and van der Weijden GC (1983a) Changes in oestradiol, progesterone and testosterone concentrations in follicular fluid and in micromorphology of preovulatory bovine follicles relative to the peak of luteinizing hormone Journal of Endocrinology 97 31-42

Dieleman SJ, Bevers MM, Poortman J and van Tol HTM (1983b) Steroid and pituitary hormone concentrations in the fluid of preovulatory bovine follicles relative to the peak of $\mathrm{LH}$ in the peripheral blood Journal of Reproduction and Fertility 69 641-649

Eckert J and Niemann H (1998) mRNA expression of leukaemia inhibitory factor (LIF) and its receptor subunits glycoprotein 130 and LIF-receptorbeta in bovine embryos derived in vitro or in vivo. Molecular Human Reproduction 4 957-965

Enright BP, Lonergan P, Dinnyes A, Fair T, Ward FA, Yang X and Boland MP (2000) Culture of in vitro produced bovine zygotes in vitro versus in vivo: implications for early embryo development and quality Theriogenology 54 659-673 
Fortune JE (1994) Ovarian follicular growth and development in mammals Biology of Reproduction 50 225-232

Freeman WM, Walker SJ and Vrana KE (1999) Quantitative RT-PCR: pitfalls and potential Biotechniques 26 112-122

Gjørret JO, Avery B, Larsson L-I, Schellander K and Hyttel P (2001) Apoptosis in bovine blastocysts produced in vivo and in vitro. Theriogenology 55321 (Abstract)

Grover PK, Stapleton AMF, Miyazawa K and Ryall RL (2001) Simple, sensitive and accurate method for the quantification of prothrombin mRNA by using competitive PCR Biochemical Journal 356 111-120

Gutierrez JA and Guerrioro V, Jr (1995) Chemical modifications of a recombinant bovine stress-inducible $70 \mathrm{kDa}$ heat-shock protein $(\mathrm{Hsp} 70)$ mimics Hsp70 isoforms from tissues Biochemical Journal 305 197-203

Heid HW, Schmidt A, Zimbelmann R et al. (1994) Cell type-specific desmosomal plaque proteins of the plakoglobin family: plakophilin 1 (band 6 protein) Differentiation 58 113-131

Hendriksen PJM, Vos PLAM, Steenweg WNM, Bevers MM and Dieleman SJ (2000) Bovine follicular development and its effect on the in vitro competence of oocytes Theriogenology 53 11-20

Ho Y, Doherty AS and Schultz RM (1994) Mouse preimplantation embryo development in vitro: effect of sodium concentration in culture media on RNA synthesis and accumulation and gene expression Molecular Reproduction and Development 38 131-141

Ho Y, Wigglesworth K, Eppig JJ and Schultz RM (1995) Preimplantation development of mouse embryos in KSOM: augmentation by amino acids and analysis of gene expression Molecular Reproduction and Development $41232-238$

Holm P and Callesen H (1998) In vivo versus in vitro produced bovine ova: similarities and differences relevant for practical application Reproduction, Nutrition and Development 38 579-594

Hyttel P, Fair T, Callesen H and Greve T (1997) Oocyte growth, capacitation and final maturation in cattle Theriogenology 47 23-32

Izadyar F, Zeinstra E, Colenbrander B, Vanderstichele HMJ and Bevers MM (1996) In vitro maturation of bovine oocytes in the presence of bovine activin A does not affect the number of embryos Animal Reproduction Science 45 37-45

Kelly DL and Rizzino A (2000) cDNA microarray analyses of genes regulated during differentiation of embryonic stem cells Molecular Reproduction and Development 56 113-123

Keskintepe L and Brackett BG (1996) In vitro developmental competence of in vitro matured bovine oocytes fertilized and cultured in completely defined media Biology of Reproduction 52 1410-1417

Khurana NK and Niemann H (2000) Energy metabolism in preimplantation bovine embryos derived in vitro or in vivo. Biology of Reproduction 62 847-856

Koch PJ, Goldschmidt MD, Zimbelmann R, Troyanovsky R and Franke WW (1992) Complexity and expression patterns of the desmosomal cadherins Proceedings National Academy of Sciences USA 89 353-357

Lequarre AS, Grisart B, Moreau B, Schuurbiers N, Massip A and Dessy F (1997) Glucose metabolism during bovine preimplantation development: analysis of gene expression in single oocytes and embryos Molecular Reproduction and Development 48 216-226

Lequarre AS, Feugang JM, Malhomme O, Donnay I, Massip A, Dessy F and Langendonckt A (2001) Expression of $\mathrm{Cu} / \mathrm{Zn}$ and $\mathrm{Mn}$ superoxide dismutases during bovine embryo development: influence of in vitro culture Molecular Reproduction and Development 58 45-53

Memili E and First NL (1999) Control of gene expression at the onset of bovine embryonic development Biology of Reproduction $\mathbf{6 1}$ 1198-1207

Niemann H (1995) Advances in cryopreservation of bovine oocytes and embryos derived in vitro and in vivo. In Reproduction and Animal Breeding: Advances and Strategies pp 117-128 Eds G Enne et al. Elsevier Biofutur, Paris

Niemann H and Wrenzycki C (2000) Alterations of expression of developmentally important genes in preimplantation bovine embryos by in vitro culture conditions: implications for subsequent development Theriogenology 53 21-34

Niemann H, Wrenzycki C, Lucas-Hahn A, Brambrink T, Kues WA and Carnwath JW (2002) Gene expression patterns in bovine in vitro produced and nuclear transfer derived embryos and their implications for early development Cloning and Stem cells 4 23-32

Parrish JJ, Susko-Parrish J, Winer MA and First NL (1988) Capacitation of bovine sperm by heparin Biology of Reproduction 38 1171-1180

Pavlok A, Lucas-Hahn A and Niemann H (1992) Fertilization and developmental competence of bovine oocytes derived from different categories of antral follicles Molecular Reproduction and Development $3163-67$

Pinheiro JC and Bates DM (2000) Mixed-Effects Models in S and S-Plus Springer-Verlag, New York

Raabe T, Bollum FJ and Manley JL (1991) Primary structure and expression of bovine poly(A) polymerase Nature 353 229-234

Ringhoffer M, Schmitt M, Karbach J, Jager E, Oesch F and Arand M (2001) Quantitative assessment of the expression of melanoma-associated antigens by non-competitive reverse transcription polymerase chain reaction International Journal of Oncology 19 983-989

Ringwald M, Schuh R, Vestweber D et al. (1987) The structure of cell adhesion molecule uvomorulin. Insights into the molecular mechanism of $\mathrm{Ca}^{2+}$-dependent cell adhesion EMBO Journal 6 3647-3653

Rizos D, Ward F, Duffy P, Boland MP and Lonergan P (2002) Consequences of bovine oocyte maturation, fertilization or early embryo development in vitro versus in vivo: implications for blastocyst yield and blastocyst quality Molecular Reproduction and Development $61234-248$

Robertson I and Nelson RE (1998) Certification of the embryos. In Manual of the International Embryo Transfer Society, $3^{\text {rd }}$ Edn, pp 103-134 Eds DA Stringfellow and SM Seidel. International Embryo Transfer Society, Savoy, IL

Rogge L, Bianchi E, Biffi M et al. (2000) Transcript imaging of the development of human $\mathrm{T}$ helper cells using oligonucleotide arrays Nature Genetics 25 96-101

Sinclair KD, Young LE, Wilmut I and McEvoy T (2000) In-utero overgrowth in ruminants following embryo culture: lessons from mice and a warning to man Human Reproduction 15 68-86

Sirard MA and Blondin P (1996) Oocyte maturation and IVF in cattle Animal Reproduction Science 42 417-426

Stenman J, Finne P, Ståhls A, Grénman R, Stenman U-H, Palotie A and Orpana A (1999) Accurate determination of relative messenger RNA levels by RT-PCR Nature Biotechnology 17 720-722

Steuerwald N, Cohen J, Herrera RJ and Brenner CA (2000) Quantification of mRNA in single oocytes and embryos by real-time rapid cycle fluorescence monitored RT-PCR Molecular Human Reproduction 6 448-453

Van de Leemput EE, Vos PLAM, Zeinstra EC, Bevers MM, van der Weijden GC and Dieleman SJ (1999) Improved in vitro embryo development using in vivo matured oocytes from heifers superovulated with a controlled preovulatory LH surge Theriogenology 52 335-349

Van Soom A and de Kruif A (1992) A comparative study of in vivo and in vitro derived bovine embryos Proceedings of the 12th Annual Meeting of the ICAR, The Hague, The Netherlands 3 1363-1365

Van Soom A, Boerjan M, Ysebaert MT and de Kruif A (1996) Cell allocation to the inner cell mass and the trophectoderm in bovine embryos cultured in two different media Molecular Reproduction and Development 45 171-182

Van Soom A, Boerjan ML, Bols PEJ, Vanroose G, Lein A, Coryn M and de Kruif A (1997a) Timing of compaction and inner cell allocation in bovine embryos produced in vivo after superovulation Biology of Reproduction 57 1041-1049

Van Soom A, Ysebaert MT and de Kruif A (1997b) Relationship between timing of development, morula morphology, and cell allocation to inner cell mass and trophectoderm in in vitro-produced bovine embryos Molecular Reproduction and Development 47 47-56

Van Wagtendonk-de-Leeuw AM, Mullaart E, de Roos AP, Merton JS, den Daas JHG, Kemp B and de Ruigh L (2000) Effects of different reproduction techniques: $\mathrm{Al}, \mathrm{MOET}$ or IVP, on health and welfare of bovine offspring Theriogenology 53 575-597

Viuff D, Avery B, Greve T, King WA and Hyttel P (1996) Transcriptional activity in in vitro produced bovine two- and four-cell embryos Molecular Reproduction and Development 43 171-179 
Viuff D, Rickords L, Offenberg H et al. (1999) A high proportion of bovine blastocysts produced in vitro are mixoploid Biology of Reproduction $\mathbf{6 0}$ $1273-1278$

Viuff D, Hendriksen PJM, Vos PLAM, Dieleman SJ, Bibby BM, Greve T, Hyttel P and Thomsen PB (2001) Chromosomal abnormalities and development kinetics in in vivo developed cattle embryos at days 2 to 5 after ovulation Biology of Reproduction 65 204-208

Watson AJ, De Sousa P, Caveney A, Barcroft LC, Natale D, Urquhart J and Westhusin ME (2000) Impact of bovine oocyte maturation media on oocyte transcript levels, blastocyst development, cell number, and apoptosis Biology of Reproduction 62 355-364

Wrenzycki C, Herrmann D, Carnwath JW and Niemann H (1996) Expression of the gap junction gene connexin43 (Cx43) in preimplantation bovine embryos derived in vitro or in vivo. Journal of Reproduction and Fertility 108 17-24

Wrenzycki C, Herrmann D, Carnwath JW and Niemann H (1999) Alterations in the relative abundance of gene transcripts in preimplantation bovine embryos cultured in medium supplemented with either serum or PVA Molecular Reproduction and Development 53 8-18

Wrenzycki C, De Sousa P, Overström EW, Duby RT, Herrmann D, Watson AJ, Niemann H, O'Callaghan D and Boland MP (2000) Effects of superovulation heifer diet type and quantity on relative mRNA abundances and pyruvate metabolism in recovered embryos Journal of Reproduction and Fertility 118 69-78

Wrenzycki C, Hermann D, Keskintepe L, Martins A, Jr, Sirisathien S, Brackett B and Niemann H (2001a) Effects of basic culture and protein supplementation on mRNA expression in preimplantation bovine embryos Human Reproduction 16 893-901

Wrenzycki C, Wells D, Herrmann D, Miller A, Oliver J, Tervit R and Niemann H (2001b) Nuclear transfer protocol affects messenger RNA expression patterns in cloned bovine blastocysts Biology of Reproduction 65 309-317

Wrenzycki C, Lucas-Hahn A, Herrmann D, Lemme E, Korsawe K and Niemann $\mathbf{H}$ (2002) In vitro production and nuclear transfer affect dosage compensation of the X-linked gene transcripts G6PD, PGK, and Xist in preimplantation bovine embryos Biology of Reproduction $\mathbf{6 6}$ 127-134

Yan H, Dobbie Z, Gruber SB, Markowitz S, Romans K, Giadiello FM, Kinzler KW and Vogelstein B (2002) Small changes in expression affect predisposition to tumorigenesis Nature Genetics $\mathbf{3 0} 25-26$

Young LE and Fairburn HR (2000) Improving the safety of embryo technologies: possible role of genomic imprinting Theriogenology $\mathbf{5 3}$ $627-648$

Young LE, Sinclair KD and Wilmut I (1998) Large offspring syndrome in cattle and sheep Reviews of Reproduction 3 155-163

Received 18 February 2002.

First decision 27 March 2002.

Revised manuscript received 19 April 2002.

Accepted 21 May 2002. 